\title{
EDITORIAL 2016: CHANGES FOR THE FUTURE
}

\author{
Daniel Matulić, Tea Tomljanović, Marina Piria
}

Faculty of Agriculture, University of Zagreb, 10000 Zagreb, Croatia

*Corresponding Author, Email: dmatulic@agr.hr

\begin{tabular}{|c|c|}
\hline & ABSTRACT \\
\hline $\begin{array}{l}\text { Keywords: } \\
\text { future } \\
\text { quality } \\
\text { De Gruyter Open } \\
\text { Croat J Fish }\end{array}$ & $\begin{array}{l}\text { By changing its editorial system, the Croatian Journal of Fisheries continues } \\
\text { to move towards a more rigorous review which is slowly but surely } \\
\text { strengthening its quality and impact. New editors-in-chief have been elected } \\
\text { and a co-operation with De Gruyter Open publishers has been established. } \\
\text { The official abbreviation of the Journal - CROAT J FISH - was released and it } \\
\text { indicated an important change in the manuscript submission process. Also, } \\
\text { this Editorial provides information on the articles published in 2015, as well } \\
\text { as a list of reviewers who participated in the review process. }\end{array}$ \\
\hline
\end{tabular}

\section{How to Cite}

Matulić, D., Tomljanović, T., Piria, M. (2016): Editorial 2016: Changes for the Future. Journal of Fisheries 74, 1-5. DOI: 10.1515/cjf-2016-0001

\section{JOURNAL STATUS}

The Croatian Journal of Fisheries (CJF) is celebrating 78 years of publishing. Electronic publishing of CJF has slowly changed all aspects of its maintenance, including the editorial process, journal production, as well as journal marketing. CJF has taken advantage of the modern technology in receiving submissions from authors, handling the peer-reviewing procedure, producing the online Journal, integrating the Journal with abstracting and indexing databases, and in promoting it via social networks (Facebook) to scientists. Although two years ago Thompson Reuters (TR) accepted CJF for evaluation, the decision is still pending. It is our belief that collaboration with De Gruyter Open publishers (indicated below) will speed up TR's final decision.

\section{COOPERATION WITH DE GRUYTER OPEN}

From the beginning of 2016, CJF has been cooperating with De Gruyter Open publishers (DGO). DGO (formerly Versita) is one of the world's leading publishers of open access scientific content. Today DGO publishes about 400 own and third-party scholarly journals across all major disciplines. Most of these journals belong to universities, research institutes, learned societies and other organisations, and are now freely available at www.degruyteropen.com.

\section{DE DE GRUYTER OPEN}

Fig 1. De Gruyter Open Logo

The key benefit for CJF from DGO service is provision of a sophisticated electronic content hosting and distribution platform (based on PubFactory technology). One of the most important aims for CJF is to become more globally visible. Published by DGO, the Journal will benefit from worldwide distribution to libraries, full text repositories and Open Access directories. In general, it is essential for scholarly journals to be covered by numerous abstracting and indexing services (A\&I) to maximise visibility, making articles easy to find for researchers. Also, CJF will be globally presented with its own website at www.degruyter.com where readers and researchers will be able to find information such as editorial staff members, journal description, instructions for authors, abstracting and indexing services which cover the Journal and much more. 
Prevention of scholarly and professional plagiarism is a major global issue in scientific publishing. Cooperating with DGO, the Journal will have access to CrossCheck leading provider of professional plagiarism detection and prevention technology used worldwide by scholarly publishers and research institutions to ensure the originality of written work before publication. We look forward to working with DGO, hopefully establishing a long-term and mutually beneficial partnership.

\section{ABBREVIATION FOR THE CROATIAN JOUR- NAL OF FISHERIES}

The use of standardized abbreviations is essential to obtain correct and validated scientific and technical citations. Most journal abbreviations are based on a word list from the ISSN's List of Title Word Abbreviations. This includes the journal lists used by BIOSIS, CASSI, PubMed and CSA. Based on the word list of abbreviations from the ISSN, official abbreviation for the Croatian Journal of Fisheries is - CROAT J FISH.

\section{NEW EDITORS-IN-CHIEF}

Assoc. prof. Marina Piria, PhD, was the editor-in-chief of the Journal until the end of 2015. She managed to significantly raise the level of the Journal's quality and made it more recognizable internationally. From the year 2016, assist. prof. Tea Tomljanović, PhD, and assist. prof. Daniel Matulic, PhD, have both been appointed the editors-inchief and they will continue raising the quality and global visibility of the Journal.

\section{NOTICE}

Although in 2015 there were no papers in the Croatian language, from now on CJF Editorial will not accept full papers written in the Croatian language. Still, papers written in English will be associated with abstracts translated into Croatian.

\section{ISSUES IN 2015}

In 2015, 11 original scientific papers, two preliminary and 22 short communications, one review paper and two supplements to fishing profession were published. The manuscripts mostly continued to cover topics in freshwater aquaculture and inland waters. Other topics covered include marine biology, water ecology, ichthyology, fish disease and genetics (Table 1). A total of 66 manuscript submissions were received in 2015.

\section{Sažetak}

\section{UVODNIK 2016: PROMJENAMA PREMA BUDUĆNOSTI}

Promjenom uredničkog sustava i njegovog načina rada, časopis se nastavlja kretati u pravcu rigoroznijih recenzija što, polagano ali sigurno, jača njegovu kvalitetu i utjecaj. Izabrani su novi glavni urednici časopisa i uspostavljena je suradnja s izdavačkom kućom De Gruyter Open. Objavljena je službena kratica časopisa - Croat J Fish - te je naznačena važna promjena kod prijave radova u CJF-u. Također, uvodnik daje podatke objavljenih članaka u 2015. godini prema tematskim cjelinama, kao i popis recenzenata koji su sudjelovali u recenzijskom postupku.

Ključne riječi: budućnost, kvaliteta, De Gruyter Open, Croat J Fish

\section{REFERENCES}

Akalin, S., İlhan, D., Özaydın, O. (2015): Length-weight relationships for 30 demersal fish species from Çandarlı Bay (North Aegean Sea, Turkey). Croatian Journal of Fisheries, 73, 73-76.

Antonović, I., Treer, T. (2015): A review of freshwater ichthyofauna research published in the Croatian journal of fisheries since 1938. Croatian Journal of Fisheries, 73, 176 - 182.

Deyrestani, A., Alavi-Yeganeh, S. A., Sadeghizadeh, M. (2015): Length-weight and length-length relationships of six ponyfish species from the Persian gulf. Croatian Journal of Fisheries, 73, 67-69.

Githukia, C. M., Ogello, E. O., Kembenya, E. M., Achieng, A. O., Obiero, K. O., Munguti, J. M. (2015): Comparative growth performance of male mono-sex and mixed sex Nile tilapia (Oreochromis niloticus L.) reared in earthen ponds. Croatian Journal of Fisheries, 73, 20-25.

Hanif, M. A., Siddik, M. A. B., Chaklader, M. R. B., Nahar, A., Mahmud, S. (2015):Fish diversity in the southern coastal waters of Bangladesh: present status, threats and conservation perspectives. Croatian Journal of Fisheries, 73, $148-161$.

Havasi, M., Kumar, S., Nagy, Z., Beliczky, G., Nagy, S., Bercsényi, M., Gál, D. (2015): Effects of feeding regime on growth feed conversion and size variation of Silurus glanis. Croatian Journal of Fisheries, 73, 142 - 147.

Hossain, M. Y., Alam, M. J. (2015): Threatened fishes of the world: Plotosus canius Hamilton, 1822 (Siluriformes: Plotosidae). Croatian Journal of Fisheries, 73, 35-36.

Hossain, M. Y., Hossain, M. A., Ahmed, Z. F., Islam, R., Hossen, M. A., Rahman, M. M., Ohtomi, J. (2015e): Threat- 
Table 1. Topics covered by the Croatian Journal of Fisheries and titles of published papers in 2015 (Original scientific paper - OS; Preliminary communication - PC; Review article - RA; Short communication - SC)

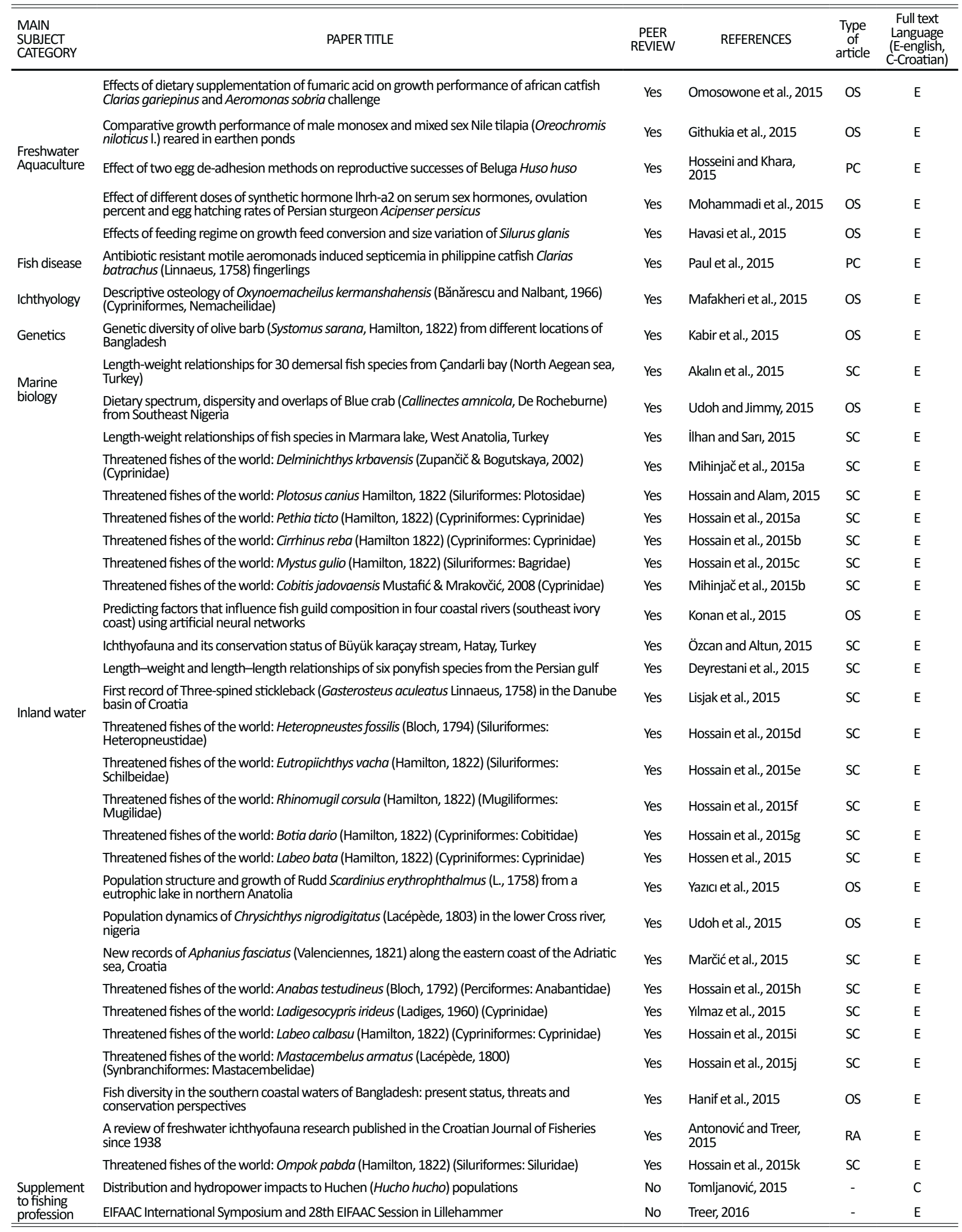


ened fishes of the world: Eutropiichthys vacha (Hamilton, 1822) (Siluriformes: Schilbeidae). Croatian Journal of Fisheries, 73, 80-82.

Hossain, M. Y., Hossain, M. A., Islam, R., Hossen, M. A., Rahman, O., Rahman, M. M. (2015a): Threatened fishes of the world: Pethia ticto (Hamilton, 1822) (Cypriformes: Cyprinidae). Croatian Journal of Fisheries, 73, 37-39

Hossain, M. Y., Hossen, M. A., Ahmed, Z. F., Yahya, K., Rahman, M. M., Ahamed, F., Ohtomi, J. (2015g): Threatened fishes of the world: Botia dario (Hamilton, 1822) (Cypriniformes: Cobitidae). Croatian Journal of Fisheries, 73, 86-88.

Hossain, M. Y., Hossen, M. A., Pramanik, M. N. U., Ahmed, Z. F., Yahya, K., Rahman, M. M., Ohtomi, J. (2015h): Threatened fishes of the world: Anabas testudineus (Bloch, 1792) (Perciformes: Anabantidae). Croatian Journal of Fisheries, 73, 128-131.

Hossain, M. Y., Hossen, M. A., Pramanik, M. N. U., Nawer, F., Ahmed, Z. F., Yahya, K., Rahman, M. M., Ohtomi, J. (2015i): Threatened fishes of the world: Labeo calbasu (Hamilton, 1822) (Cypriniformes: Cyprinidae). Croatian Journal of Fisheries, 73, 134-136.

Hossain, M. Y., Hossen, M. A., Yahya, K., Ahmed, Z. F., Sarder, M. R. I., Islam, M. A., Ahmed, K. K. U. (2015j):Threatened fishes of the world: Mastacembelus armatus (Lacepede, 1800) (Synbranchiformes: Mastacembelidae). Croatian Journal of Fisheries, 73, 137 - 139.

Hossain, M. Y., Hossen, M. A., Yahya, K., Islam, M. M., Islam, M. A., Ahmed, K. K. U., Begum, M. (2015k): Threatened fishes of the world: Ompok pabda (Hamilton, 1822) (Siluriformes: Siluridae). Croatian Journal of Fisheries, 73, $183-185$.

Hossain, M. Y., Islam, R., Ahmed, Z. F., Rahman, M. M., Hossen, M. A., Naser S. M. A., Rasel, R. I. (2015d): Threatened fishes of the world: Heteropneustes fossilis (Bloch, 1794) (Siluriformes: Heteropneustidae). Croatian Journal of Fisheries, 73, 77-79.

Hossain, M. Y., Islam, R., Hossain, M. A., Hossen, M. A., Rahman, M. M., Ohtomi, J. (2015b): Threatened fishes of the world: Cirrhinus reba (Hamilton 1822) (Cypriniformes: Cyprinidae). Croatian Journal of Fisheries, 73, 40-42

Hossain, M. Y., Islam, R., Hossen, M. A., Rahman, O., Hossain, M. A., Islam, M. A., Alam, M. J. (2015c): Threatened fishes of the world: Mystus gulio (Hamilton, 1822) (Siluriformes: Bagridae). Croatian Journal of Fisheries, 73, 43-45.

Hossain, M. Y., Islam, R., Yahya, K., Rahman, M. M., Hossen, M. A., Abu Naser, S. M., Rasel, R. I. (2015): Threatened fishes of the world: Rhinomugil corsula (Hamilton, 1822) (Mugiliformes: Mugilidae). Croatian Journal of Fisheries, 73, 83-85.

Hosseini, S. H., Khara H. (2015): Effect of two egg deadhesion methods on reproductive successes of beluga Huso huso. Croatian Journal of Fisheries, 73, 26-29.

Hossen, M. A., Hossain, M. Y., Yahya, K. Pramanik, M. N. A. (2015): Threatened fishes of the world: Labeo bata (Hamilton, 1822) (Cypriniformes: Cyprinidae). Croatian Journal of Fisheries, 73, 89-91.

Kabir, A., Habib, M. A., Hossain, A., Mandal, S. C. (2015): Genetic diversity of olive barb (Systomus sarana, Hamilton, 1822 ) from different locations of Bangladesh. Croatian Journal of Fisheries, 73, 6-12.

Konan, K. F., Bony, K. Y., Edia, O. E., Aliko, N. G., Ouattara, A., Gourene, G. (2015): Predicting factors that influence fish guild composition in four coastal rivers (southeast Ivory Coast) using artificial neural networks. Croatian Journal of Fisheries, 73, 48-57.

Ihan, A., Sari, H. M. (2015): Length-weight relationships of fish species in Marmara lake, West Anatolia, Turkey. Croatian Journal of Fisheries, 73, 30-32.

Lisjak, D., Zanella, D., Mustafić, D., Ćaleta, M., Buj, I., Mihinjač, T., Mrakovčić, M., Marčić, Z. (2015): First record of threespined stickleback (Gasterosteus aculeatus Linaeus, 1758) in the Danube basin of Croatia. Croatian Journal of Fisheries, 73, 70-72.

Mafakheri, P., Eagderi, S., Farahmand, H., Mosavii-Sabet, H. (2015): Descriptive osteology of Oxynoemacheilus kermanshahensis (Bănărescu and Nalbant, 1966) (Cypriniformes, Nemacheilidae). Croatian Journal of Fisheries, 73, 115-123.

Marčić, Z., Ćaleta, M., Buj, I., Zanella, D., Mustafić, P., Mihinjač, T., Mrakovčić, M. (2015): New records of Aphanius fasciatus (Valenciennes, 1821) along the eastern coast of the Adriatic sea in Croatia. Croatian Journal of Fisheries, 73, 124-127.

Mihinjač, T., Marčić, Z., Buj, I., Zanella, D., Mustafić, P., Mrakovčić, M., Ćaleta, M. (2015a): Threatened fishes of the world: Delminichthys krbavensis (Zupančič \& Bogutskaya, 2002) (Cyprinidae). Croatian Journal of Fisheries, 73, 33-34.

Mihinjač, T., Marčić, Z., Mrakovčić, M., Mustafić, P., Zanella, D., Buj, I., Ćaleta, M. (2015b): Threatened fishes of the world: Cobitis jadovaensis Mustafić \& Mrakovčić, 2008 (Cyprinidae). Croatian Journal of Fisheries, 73, 46-47.

Mohammadi, H., Khara, H., Kazemi, R. (2015): Effect of different doses of synthetic hormone LHRH-A2 on serum sex hormones, ovulation percent and egg hatching rates of Persian sturgeon Acipenser persicus. Croatian Journal of Fisheries, 73, 58-62.

Omosowone, O., Dada, A., Adeparusi, E. (2015): Effects of dietary supplementation of fumaric acid on growth performance of African catfish Clarias gariepinus and Aeromonas sobria hallenge. Croatian Journal of Fisheries, 73, 13-19.

Özcan, G., Altun, A. (2015): Ichthyofauna and its conservation status of Büyük Karaçay stream, Hatay, Turkey. Croa- 
tian Journal of Fisheries, 73, 63-66.

Paul, P., Adikesavalu, H., Banerjee, S., Abraham, T. J. (2015): Antibiotic resistant motile aeromonads induced septicemia in Philippine catfish Clarias batrachus (Linnaeus, 1758) fingerlings. Croatian Journal of Fisheries, 73, 170 $-175$.

Tomljanović, T. (2015): Distribution and hydropower impacts to Huchen (Hucho hucho) populations. Croatian Journal of Fisheries, 73, 92-93.

Treer, T. (2015): EIFAAC International Symposium and 28th EIFAAC Session in Lillehammer. Croatian Journal of Fisheries, $73,140-141$.

Udoh, J. P., Jimmy, U. U. (2015): Dietary spectrum, dispersity and overlaps of Blue crab (Callinectes amnicola, de Rocheburne) from southeast Nigeria. Croatian Journal of Fisheries, 73, 162 - 169.

Udoh, J. P., Ukpatu, J. E., Udoidiong, O. M. (2015): Population dynamics of Chrysichthys nigrodigitatus (Lacépčde, 1803) in lower Cross river, Nigeria. Croatian Journal of Fisheries, 73, 103-114.

Yazici, R., Yilmaz, S., Yazicioğlu, O., Polat, N. (2015): Population structure and growth of rudd Scardinius erythrophthalmus (L., 1758) from a eutrophic lake in northern Anatolia. Croatian Journal of Fisheries, 73, 94-102.

Yilmaz, F., Yorulmaz, B., Giannetto, D. (2015): Threatened fishes of the world: Ladigesocypris irideus (Ladiges, 1960) (Cyprinidae). Croatian Journal of Fisheries, 73, 132-133.
Appendix 1. List of reviewers for the Croatian Journal of Fisheries between 1 January 2015 and 31 December 2015



\author{
Laith Jawad \\ Linda Zanella \\ Lorenzo Vilizzi \\ Mahdi Goshlan \\ Manouchehr Nasri \\ Marcelo Kovačić \\ Marina Piria \\ Md. Yeamin Hossain \\ Mirjana Lenhardt \\ Mohaddeseh Ahmadnezhad \\ Nejdet Gültepe \\ Parviz Zare \\ Pavel Jurajda \\ Pero Tutman \\ Predrag Ivanković \\ Radek Sanda \\ Rafael Miranda Ferreiro \\ Rajeev Rhagavan \\ Rashmi Dutta \\ Robert L. Vadas Jr. \\ Saleha Jasmine \\ Sandipan Pal \\ Slobodan Regner \\ Tea Tomljanović \\ Teppo Vehanen \\ Tomislav Treer \\ Vesna Djikanović \\ Vesna Poleksić \\ Vlastimil Stejskal \\ Vlatka Filipović Marijić \\ Xiaojuan Cao \\ Zdzislaw Zakes \\ Zexia Gao \\ Zrinka Knezović
}

